\title{
Studies on the Productivity and Nutrient Element Circulation in Kirigamine Grassland, Central Japan II. Seasonal Change in Standing Crop
}

\author{
by Hideo Iwaki*, Bunziro Midorikawa** and Kinji Hogetsu**
}

\section{Received August 25, 1964}

In the present study, seasonal change in standing crop was investigated in order to determine the annual net production of natural herbaceous communities in Mt. Kirigamine, Nagano Prefecture. Climate, soil conditions and vegetation patterns in this grassland were reported in a previous paper ${ }^{11}$.

A number of authors ${ }^{2-8}$ have so far been concerned with the productivity of herbaceous communities, though many of these were of cultivated plants and pasture crops. Concerning the uncultivated herbaceous communities in Japan, many standing crop data ${ }^{9-20)}$ (mainly in fresh weight) have been accumulated especially on Miscanthus sinensis-type community, the most important and familiar type in montane grassland of this country. To date, however, only a little has been written about the annual net production of $M$. sinensis-type community, in spite of its importance in the use and management of grassland.

The method for determining the annual net production of herbaceous community is usually based on studying the annual change in standing crop, both above-ground and underground. In a plant community consisting of many species, however, seasonal peak standing crop of the vegetation as a whole is in most cases smaller than the sum total of peak standing crop of each constituent species ${ }^{4,7)}$, since different species attain their peak standing crop at different times of a year. So, standing crop determination of each species in a community should be made at frequent intervals, in order to obtain a reasonable estimate of the annual net production. In the present paper, seasonal changes in standing crop of the whole vegetation as well as of each species in Miscanthus sinensis-type and Arundinella hirta-type communities will be presented on the basis of the monthly investigations which were carried out in 1959 and 1960. Moreover, data on the productive structure of some herbaceous communities will be provided.

\section{Productive structure of the grassland communities}

As shown in a previous paper ${ }^{1)}$, the most important vegetation types in Kirigamine grassland are Miscanthus-, Arundinella-, and Sasa-type community. These communities were rather differentiated in species composition and in productive structure.

Using the stratified-clip method devised by Monsi and Saeki ${ }^{21}$, the vertical distribution pattern of photosynthetic system (leaves) and non-photosynthetic system (mainly stems) was determined for each main constituent species in the community. In Miscanthus-, Arundinella-, and Sasa-type community, the measurement was made

A part of expense was supported by a Grant in Aid of Scientific Research of Ministry of Education.

* Department of Botany, Faculty of Science, University of Tokyo, Tokyo, Japan.

** Department of Biology, Faculty of Science, Tokyo Metropolitan University, Tokyo, Japan. 
in late August, when seasonal peak of above-ground standing crop was nearly attained. The vertical distribution patterns of leaves and stems in $g$ dry weight $/ \mathrm{m}^{2}$, i.e., "the productive structure diagrams", were given in Fig. 1.

The height of $M$. sinensis-type community (Fig. 1-B) was about $120 \mathrm{~cm}$ in late August, and the upper layer of the community $(40-120 \mathrm{~cm})$ was mostly occupied by Miscanthus sinensis, which made the largest contribution to the community standing crop. In the lower layer $(0-40 \mathrm{~cm})$ some forbs such as Aster scaber, Ligularia stenocephala, Solidago virga-aurea and Lespedeza cyrtobotrya occurred. Because of the serious light interception by foliage, mostly of Miscanthus sinensis, relative light intensity in the lower layer was reduced to about 3-5\% of incident light. This seems to affect the forb species in the lower layer to reduce dry matter production.

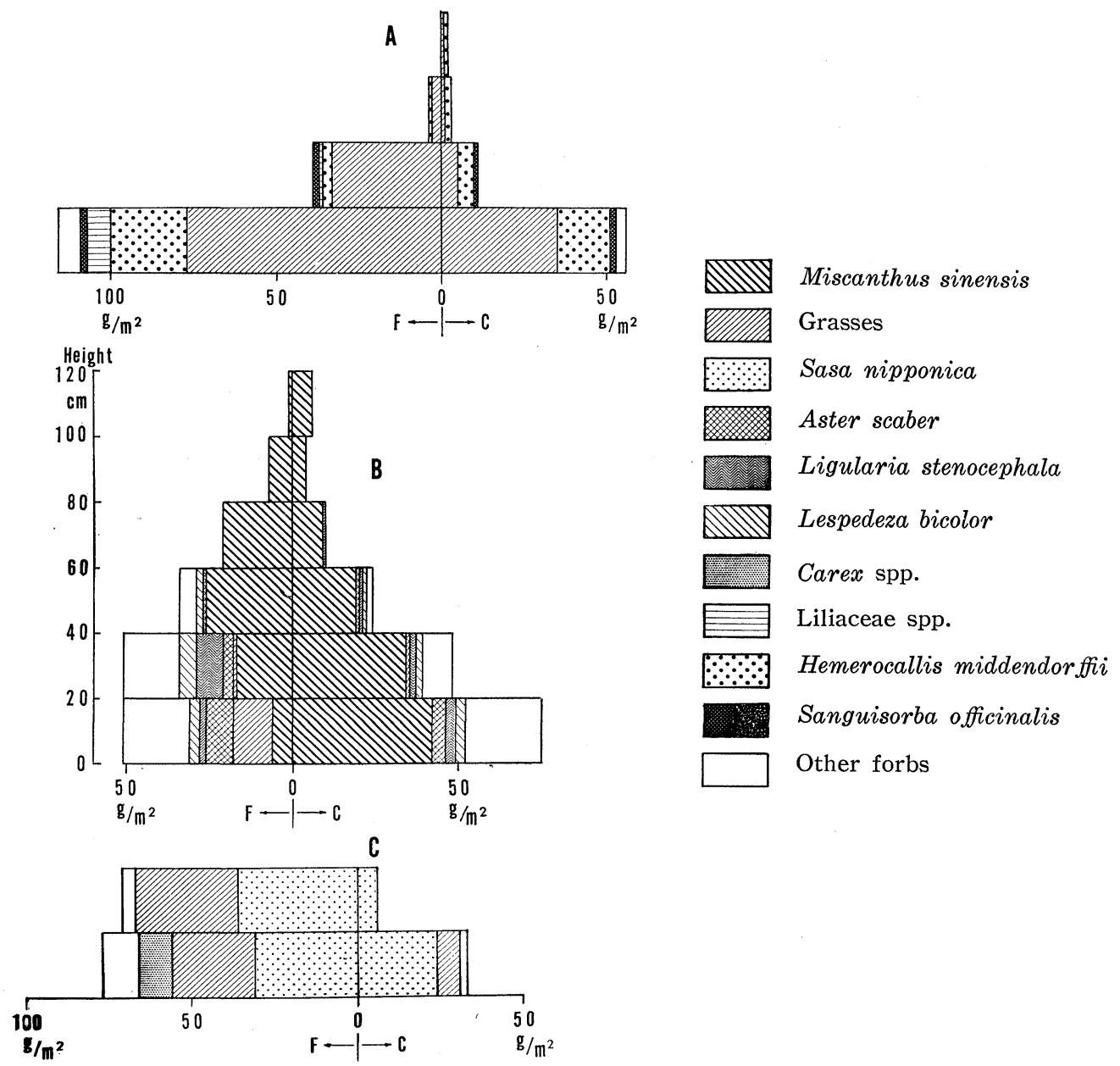

Fig. 1. Productive structure diagrams of plant communities in Kirigamine grassland. A, Arundinella hirta-type community in stand-I (August 21, 1959); B, Miscanthus sinensistype community in stand-II (August 23, 1959); C, Sasa nipponica-type community (August 10, 1961). Photosynthetic system (F) consists of laminae, and non-photosynthetic system (C), of stems, petioles, culms, etc. 
The productive structure of Arundinella hirta-type community was rather different from that of Miscanthus-type community. The Arundinella-type community was about $80 \mathrm{~cm}$ in height, and showed no marked stratification in the vertical distribution of foliage of component species (Fig. 1-A). The greater part of the foliage was distributed in the lower layer, $0-20 \mathrm{~cm}$ above ground-level, and relative light intensity in the lower layer was much higher (10-25\%) than that in the Miscanthustype community.

\section{Seasonal change in standing crop}

The growing season of plants in Kirigamine grassland begins in May and ends by November, showing marked seasonal change in above-ground standing crop. For the determination of seasonal change in standing crop, two plots, each $50 \times 50 \mathrm{~m}^{2}$ in area, were staken in stand-I (Arundinella hirta type) and stand-II (Miscanthus sinensis type). Determination of standing crop was made at one month interval during the growing season from May to November in 1959 and 1960. At each monthly sampling, all the vegetation, both above-ground and underground, and litter were removed from three $1 \mathrm{~m}^{2}$ quadrats, and oven-dry weight of major constituent species and groups of species was determined. In Table 1 is given seasonal change in standing crop of living plant material and in litter during the growing period for stand-I and -II in terms of $\mathrm{g}$ dry weight $/ \mathrm{m}^{2}$. The standing crop data in Table 1 are in general for living parts. The only exception for this is underground standing crop of grasses (excluded Miscanthus sinensis and Sasa nipponica), in which separation

Table 1. Mean standing crop of above-ground and underground vegetation and amount of litter on the ground surface, based on the monthly samplings in 1959.

A: Arundinella hirta-type community (stand-I).

\begin{tabular}{l|rr|r|r}
\hline \multirow{2}{*}{ Date } & \multicolumn{2}{|c|}{ Mean standing crop } & $\mathrm{g} / \mathrm{m}^{2}$ & \multirow{2}{*}{ Litter $\mathrm{g} / \mathrm{m}^{2}$} \\
\cline { 2 - 5 } & Above-ground & Underground & Total & \\
\hline May 22 & 17 & 456 & 473 & 188 \\
June 21 & 86 & 502 & 588 & 84 \\
July 23 & 206 & 417 & 623 & 76 \\
August 21 & 265 & 402 & 667 & 98 \\
September 29 & 220 & 430 & 650 & 76 \\
November 14 & 7 & - & - & 208 \\
\hline
\end{tabular}

B: Miscanthus sinensis-type community (stand-II).

\begin{tabular}{l|rr|r|r}
\hline \multirow{2}{*}{ Date } & \multicolumn{2}{|c|}{ Mean standing crop } & $\mathrm{g} / \mathrm{m}^{2}$ & \multirow{2}{*}{ Litter g/m $\mathrm{m}^{2}$} \\
\cline { 2 - 4 } & Above-ground & Underground & Total & \\
\hline May 24 & 20 & 673 & 693 & 108 \\
June 23 & 53 & 567 & 620 & 275 \\
July 25 & 204 & 487 & 691 & 394 \\
August 23 & 365 & 717 & 1082 & - \\
October 1 & 289 & 600 & 889 & 434 \\
November 16 & 8 & 610 & 618 & 431 \\
\hline
\end{tabular}


of dead plant parts from living one being very difficult.

(1) Above-ground standing crop of the whole vegetation: In May, soon after the snow-melt, above-ground standing crop began to increase, and reached its maximum by late August (stand-I) or early:
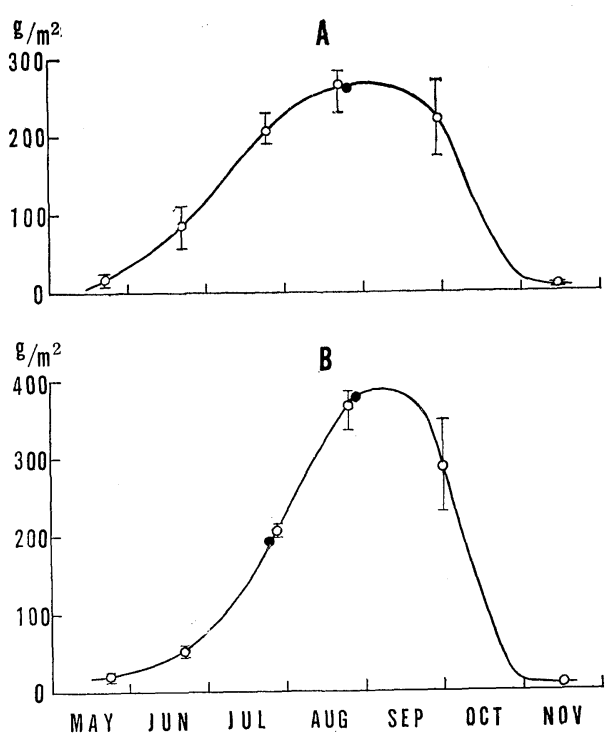

Fig. 2. Seasonal change in aboveground standing crop (g dry weight $/ \mathrm{m}^{2}$ ) in 1959. A, Arundinella hirta-type community (stand-I); B, Miscanthus sinensis-type community (stand-II). Solid circles represent standing crop values based on the sampling of vegetation on large area. September (stand-II), then it decreased rapidly towards the end of growing season in November. The seasonal peak standing crop in dry weight of above-ground vegetation was ca. $270 \mathrm{~g} / \mathrm{m}^{2}$ for stand-I and ca. $380 \mathrm{~g} / \mathrm{m}^{2}$ for stand-II (Fig. 2).

(2) Underground standing crop of the whole vegetation: Regular monthly sampling of underground part (root and subterranean stem) from three $1 \mathrm{~m}^{2}$ quadrats during the growing season gave the mean values of the underground standing crop in Table 1 , which ranged from $487 \mathrm{~g}$ dry weight $/ \mathrm{m}^{2}$ in July to $717 \mathrm{~g} / \mathrm{m}^{2}$ in August for stand-II (Miscanthus type), and from $402 \mathrm{~g} / \mathrm{m}^{2}$ in August to $502 \mathrm{~g} / \mathrm{m}^{2}$ in June for stand-I (Arundinella type). As. deviation of the values of underground. standing crop was considerably large in comparison with those of above-ground part, no distinct seasonal trend could be found in underground standing crop.

In order to get more reliable data on the underground standing crop of $M$. sinensis community at the initial developmental stage, eleven $1 \mathrm{~m}^{2}$ quadrats were sampled from standII during the period from October to May; i.e. three quadrats in mid-October, four in midNovember, one in late April and three in late May. In this cool period, plant activities such as translocation and growth are so low that change in dry weight of underground part is negligibly small as compared with total biomass of underground parts. The smallest and largest underground standing crop of these quadrats was $277 \mathrm{~g} / \mathrm{m}^{2}$ and $839 \mathrm{~g} / \mathrm{m}^{2}$, respectively, and the average was $600 \mathrm{~g} / \mathrm{m}^{2}\left( \pm 93 \mathrm{~g} / \mathrm{m}^{2}\right.$ of $95 \%$ confidence limit). It follows from this that underground standing crop of Miscanthus sinensis-type community in Kirigamine is around $600 \mathrm{~g} / \mathrm{m}^{2}$ in the dormant period in winter.

Bray $^{2}$ has collected many data about the shoot-root ratio of some annual plants and found that the ratio varied from 11.6 for Zizania aquatica to 0.37 for Secale cereale. In Kirigamine grassland, most species were perennial plants and the underground/above-ground ratio in dry weight of the whole vegetation was about 1.5 for stand-I and 2.0 for stand-II in late August. The ratio was, however, very diverse among the constituent species, ranging from 0.14 for Scabiosa japonica to 9.5-11.3 for Sasa nipponica (Table 2). The underground/above-ground ratio of individual species also showed a characteristic seasonal change, and the seasonal minimum was attained at different times of a year; e.g. in June for Hemerocallis; 
Table 2. Standing crop $\left(\mathrm{g} / \mathrm{m}^{2}\right)$ of above-ground part ( $\mathrm{F}$, laminae; $\mathrm{C}$, stems, culms and petioles) and underground part, and ratio of underground to aboveground standing crop (on dry weight basis) of each major species.

A: Arundinella hirta-type community (stand-I). August 21, 1959.

\begin{tabular}{|c|c|c|c|c|c|c|}
\hline \multirow{2}{*}{ Species } & \multicolumn{3}{|c|}{ Above-ground parts } & \multirow{2}{*}{$\begin{array}{c}\text { Under- } \\
\text { ground } \\
\text { parts } \mathrm{g} / \mathrm{m}^{2}\end{array}$} & \multirow{2}{*}{$\begin{array}{c}\text { Total } \\
\mathrm{g} / \mathrm{m}^{2}\end{array}$} & \multirow{2}{*}{$\begin{array}{c}\text { Underground/ } \\
\text { above-ground } \\
\text { ratio }\end{array}$} \\
\hline & $\mathrm{F} \mathrm{g} / \mathrm{m}^{2}$ & $\mathrm{C} \mathrm{g} / \mathrm{m}^{2}$ & Total $\mathrm{g} / \mathrm{m}^{2}$ & & & \\
\hline Sasa nipponica & 0.5 & 0.6 & 1.1 & 12.4 & 13.5 & 11.27 \\
\hline other grasses \& Carex spp. & 112.8 & 41.7 & 154.5 & 291.0 & 445.5 & 1.88 \\
\hline Hemerocallis middendorffii & 3.3 & - & 3.3 & 28.3 & 31.6 & 8.57 \\
\hline Scabiosa japonica & 26.4 & 23.9 & 50.3 & 6.9 & 57.2 & 0.14 \\
\hline Sanguisorba officinalis & 4.6 & 2.7 & 7.3 & 17.7 & 25.0 & 2.42 \\
\hline Disporum smilacinum & 3.2 & 0.7 & 3.9 & 6.2 & 10.1 & 1.59 \\
\hline Convallaria majalis & 1.6 & 0.4 & 2.0 & 6.7 & 8.7 & 3.35 \\
\hline Hosta lancifolia & 0.6 & 0.3 & 0.9 & 8.3 & 9.2 & 9.22 \\
\hline other forbs & 6.5 & 2.3 & 8.8 & 12.7 & 21.5 & 1.44 \\
\hline Total & 159.5 & 72.6 & 232.1 & 390.2 & 622.3 & \\
\hline
\end{tabular}

B: Miscanthus sinensis-type community (stand-II). August 23, 1959.

\begin{tabular}{|c|c|c|c|c|c|c|}
\hline \multirow{2}{*}{ Species } & \multicolumn{3}{|c|}{ Above-ground parts } & \multirow{2}{*}{\begin{tabular}{|c|} 
Under- \\
ground \\
parts $\mathrm{g} / \mathrm{m}^{2}$
\end{tabular}} & \multirow{2}{*}{$\begin{array}{c}\text { Total } \\
\mathrm{g} / \mathrm{m}^{2}\end{array}$} & \multirow{2}{*}{$\begin{array}{l}\text { Underground } / \\
\text { above-ground } \\
\text { ratio }\end{array}$} \\
\hline & $\mathrm{F} \mathrm{g} / \mathrm{m}^{2}$ & $\mathrm{C} \mathrm{g} / \mathrm{m}^{2}$ & Total $\mathrm{g} / \mathrm{m}^{2}$ & & & \\
\hline Miscanthus sinensis & 77.4 & 114.2 & 191.6 & 389.0 & 580.6 & 2.03 \\
\hline Sasa nipponica & 1.6 & 0.8 & 2.4 & 22.9 & 25.3 & 9.54 \\
\hline other grasses \& Carex spp. & 13.4 & - & 13.4 & 35.8 & 49.2 & 2.67 \\
\hline Aster scaber & 12.3 & 7.6 & 19.9 & 10.3 & 30.2 & 0.52 \\
\hline Ligularia stenocephala & 10.2 & 8.7 & 18.9 & 16.5 & 35.4 & 0.87 \\
\hline Lespedeza bicolor & 9.1 & 6.6 & 15.7 & 10.2 & 25.9 & 0.65 \\
\hline Sanguisorba officinalis & 2.2 & 0.9 & 3.1 & 15.3 & 18.4 & 4.94 \\
\hline other forbs & 37.5 & 32.1 & 69.6 & 66.6 & 136.2 & 0.96 \\
\hline Total & 163.7 & 170.9 & 334.6 & 566.6 & 901.2 & \\
\hline
\end{tabular}

middendorffi (1.78), Disporum smilacinum (0.92) and Convallaria majalis (2.84), in late July for Solidago virga-aurea (0.67), and in late August for Miscanthus sinensis (2.12) and other grasses (3.17).

(3) Litter amount: Amount of dead plant material (litter) on the ground surface reached its maximum value at the end of growing season, in October or November. The maximum litter amount was about $200 \mathrm{~g}$ dry weight $/ \mathrm{m}^{2}$ for stand-I and $430 \mathrm{~g} / \mathrm{m}^{2}$ for stand-II. Most of the litter can be decomposed during the summer period from June to August, showing marked decrease in litter amount. Decomposition rate of litter appeared to be more rapid in Arundinella type than in Miscanthus-type community.

(4) Standing crop of each constituent species: Vegetation in Kirigamine grassland also showed a marked seasonal change in standing crop of constituent species. In Figs. 3-A and $-\mathrm{B}$ seasonal change in above-ground standing crop of 
main constituent species and species groups is shown for stand-I and stand-II.
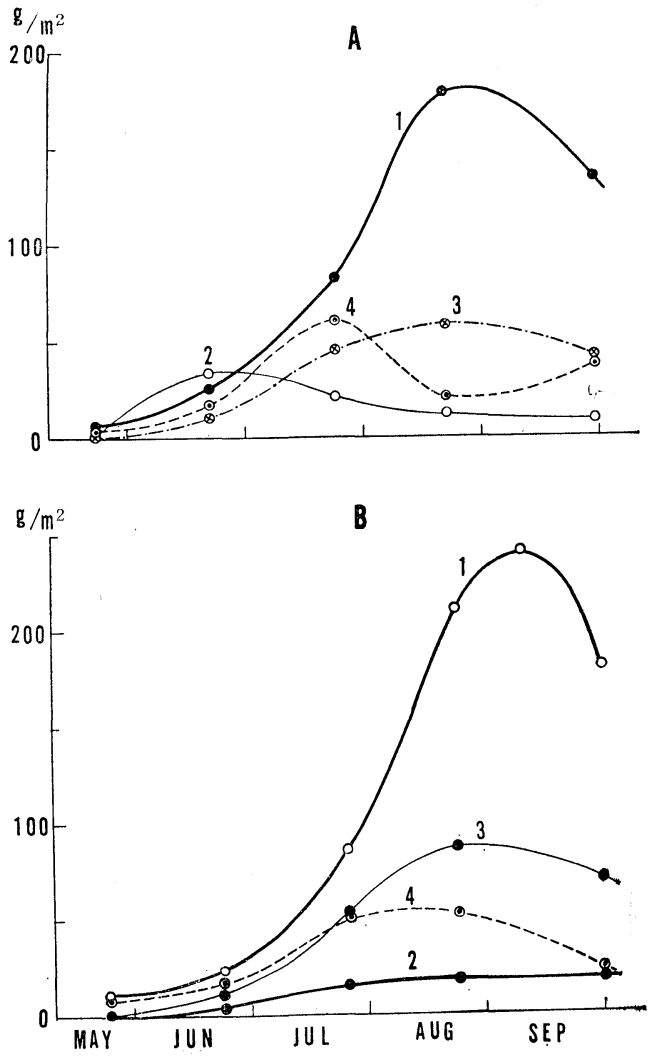

Fig. 3. Seasonal change in the above-ground standing crop of each major species and species group.

A: stand-I (Arundinella hirta-type). 1, grasses (Arundinella hirta, Miscanthus sinensis, Calamagrostis arundinacea, etc.) and Carex species; 2, Hemerocallis middendorffi; 3, Scabiosa japonica; 4, other forbs (Sanguisorba officinalis, Adenophora triphylla var. japonica, Solidago virga-aurea, Eupatorium sachalinense, Gentiana makinoi, Pteridium aquilinum, Potentilla freyniana, P. fragarioides var. sprengeliana, Artemisia japonica, Peucedanum decursivum, etc.).

B: stand-II (Miscanthus sinensis-type). 1, Miscanthus sinensis; 2, other grasses; 3, Compositae species (Solidago virga-aurea, Aster ageratoides var. ovatus, A. scaber, Anaphalis margaritacea, Artemisia vulgaris var. vulgatissima, Serratula coronata, Synurus pungens, Ligularia stenocephala, Cirsium japonicum, etc.); 4, other forbs (Lespedeza bicolor var. japonica, Sanguisorba officinalis, Angelica polyclada, etc.).
In Arundinella-type community (standI) some grass species, such as Arundinella hirta, Miscanthus sinensis and Calamagrostis arundinacea, made the largest contribution to the above-ground standing crop of the community especially in late August, when cutting of forage was usually made in this area (Fig. 3-A). In June some species of Liliaceae, such as Hemerocallis middendorffi, Convallaria majalis and Disporum smilacinum, were dominant. By late July, however, these species reduced their above-ground standing crop and gave way to grasses or Scabiosa japonica. Standing crop of other miscellaneous forbs reached their maxima by late July or by early August. The seasonal peak value of above-ground standing crop for grasses, Liliaceae species, Scabiosa japonica, and other forbs in stand-I, was $180 \mathrm{~g} / \mathrm{m}^{2}, \quad 34 \mathrm{~g} / \mathrm{m}^{2}, \quad 58 \mathrm{~g} / \mathrm{m}^{2}$ and $60 \mathrm{~g} / \mathrm{m}^{2}$, respectively (Fig. 3-A). Thus the sum total of these values is $332 \mathrm{~g} / \mathrm{m}^{2}$, which being rather large as compared with the seasonal peak aboveground standing crop of the community as a whole (ca. $270 \mathrm{~g} / \mathrm{m}^{2}$, in late August).

In Miscanthus-type community (standII), Miscanthus sinensis assumed the largest proportion (40-60\%) in the aboveground standing crop of the community throughout the growing season and attained its seasonal peak, about $240 \mathrm{~g} / \mathrm{m}^{2}$, in early September. Compositae species, such as Aster, Solidago, Anaphalis and Cirsium, followed $M$. sinensis in rank of above-ground standing crop (Fig. 3-B), and its seasonal peak value in late August was $87 \mathrm{~g} / \mathrm{m}^{2}$. The seasonal peak standing crop for other grasses and other miscellaneous forbs was $18 \mathrm{~g} / \mathrm{m}^{2}$ (in early September) and $54 \mathrm{~g} / \mathrm{m}^{2}$ (in early August), respectively. Thus the sum of these peak values of constituent species in stand-II is $399 \mathrm{~g} / \mathrm{m}^{2}$, which is slightly larger than the seasonal peak in above-ground standing crop of the whole vegetation. 
Since individual species showed characteristic seasonal pattern in standing crop, the proportion of constituent species in harvested forage should be changed with the time of cutting. Thus in Miscanthus-type community, the later the time of cutting, the larger the proportion of Miscanthus sinensis and the smaller that of Compositae species. In Arundinella-type community, on the other hand, Hemerocallis middendorffi and other Liliaceae species made a great contribution to the forage yield by the cutting from June to early July. While by the cutting in late August or later, grasses formed a larger proportion, about $60 \%$, to the total yield and Scabiosa japonica came after that in rank.

In Kirigamine, most constituent species of grassland community are perennial plants, which accumulate in their subterranean parts (rhizomes or tubers) a considerable amount of organic matter. With this reserve matter, plants are able to develop their aerial parts very rapidly in spring, as was shown by Midorikawa ${ }^{22)}$ for tall herb community (Altherbosa) at Mt. Hakkôda. At the end of growing season, surplus organic matter produced by photosynthesis of the aerial part is transported again to the underground part. Thus it is expected that with the seasonal movement of reserve organic matter between above-ground and underground parts, the ratio of top weight to total plant weight will also show a seasonal change.

Seasonal changes in the top/total weight ratio (\%) for some major species in Kirigamine grassland are shown in Fig. 4. In many of the constituent species, the ratio began to increase from nearly zero immediately after the emergence of buds, approaching to seasonal maximum value, and then decreased rapidly till the end of growing period. An exception for this was Scabiosa japonica, which passed winter with rosette-form leaves. So the top/total weight ratio did not reach zero even in December. In Fig. 4, several types of seasonal pattern are distinguishable in reference to the time of maximum ratio as follows: I. Liliaceae type, Hemerocallis, Convallaria and Disporum, showing a maximum in late June; II. Scabiosa japonica type, in which the ratio was very large throughout the growing season with a

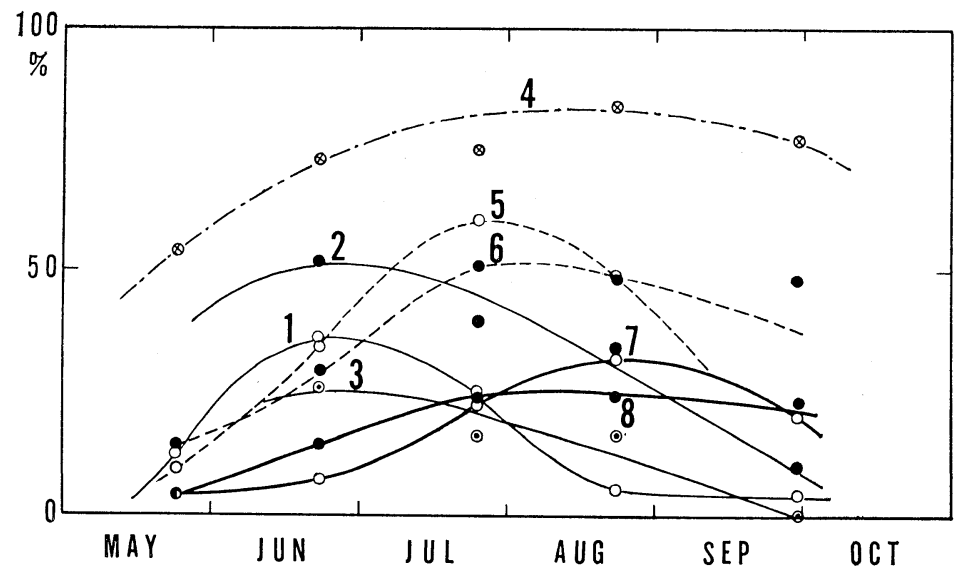

Fig. 4. Seasonal change in the ratio of top weight to total plant weight of each major species during the growing season. Liliaceae type $\left(1, H_{t}\right.$ * merocallis middendorffii; 2, Disporum smilacinum; 3, Convallaria majalis). Scabiosa japonica type (4, Scabiosa japonica). Compositae type (5, Solidago virga-aurea; 6, Aster ageratoides). Grass type (7, Miscanthus sinensis; 8, Arundinella hirta, Calamagrostis arundinacea). 
maximum in August; III. Compositae type, Solidago, Aster and other Compositae species, with a maximum in late July; IV. Grass type, Miscanthus sinensis, Arundinella hirta and other grasses, with a maximum in late August or later.

It is expected from these results that cutting of forage at the stage of the maximum ratio will exert an inhibitive effect on plant growth in the next year by reducing the amount of reserve matter to be accumulated in subterranean stems by the end of the growing season. Thus it seemed reasonable to assume that plant species which is most susceptible to cutting damage differs with the time of cutting; e.g. Liliaceae species suffer most seriously by the cutting from late June to early July, Scabiosa japonica and Compositae species by the cutting from late July to early August, and Miscanthus sinensis by the cutting from late August to early September.

\section{Comparison of above-ground standing crop among various grasslands in Japan}

On August 27, 1959, further twelve quadrats, each $5 \times 5 \mathrm{~m}^{2}$ in size, were sampled from stand-II for the accurate determination of the above-ground standing crop. All plants in the quadrat were cut with a scythe and oven-dry weight of grasses and forbs harvested were determined. The results expressed in gram dry weight per square meter are as follows:

$$
261,300,322,365,328,260,377,296,233,336,320,246 .
$$

Mean: $304 \mathrm{~g} / \mathrm{m}^{2}, 95 \%$ confidence limit: $\pm 29 \mathrm{~g} / \mathrm{m}^{2}$.

As cutting was made with a scythe, and the lowermost part of the vegetation, $0-10 \mathrm{~cm}$ above ground-level, was not harvested by this procedure, the obtained mean standing crop, $304 \mathrm{~g} / \mathrm{m}^{2}$, must be corrected for the unharvested part. The plant biomass existing in $0-10 \mathrm{~cm}$ layer in late August was estimated to be $65 \mathrm{~g} / \mathrm{m}^{2}$, about $19 \%$ of the above-ground biomass, on the basis of the productive structure diagram of Miscanthus-type community (Fig. 1-B). Thus estimate of the mean above-ground standing crop was obtained by the following calculation:

$$
304 \times 100 /(100-19)=376 \mathrm{~g} / \mathrm{m}^{2} \text {. }
$$

This value agrees fairly well with the above-ground standing crop, $365 \mathrm{~g} / \mathrm{m}^{2}$, which was obtained from the sampling in August of three $1 \mathrm{~m}^{2}$ quadrats (Fig. 2-B).

Similar measurement was also made in stand-I (Arundinella type), from which twenty quadrats, each $5 \times 5 \mathrm{~m}^{2}$ in size, were sampled on August 25, 1959. Cutting procedure in stand-I was similar as that in stand-II. The obtained results are as follows:

$$
\begin{aligned}
& 227,227,187,209,211,221,134,202,181,180, \\
& 156,173,222,206,196,220,179,175,192,226 .
\end{aligned}
$$

Mean: $196 \mathrm{~g} / \mathrm{m}^{2}, 95 \%$ confidence limit: $\pm 12 \mathrm{~g} / \mathrm{m}^{2}$.

Correction for the lowest vegetation part, which was not harvested by the cutting with a scythe, was also made in the similar manner as in stand-II. On the basis of the productive structure of Arundinella-type community (Fig. 1-A), biomass of the unharvested vegetation was estimated to be about $60-70 \mathrm{~g} / \mathrm{m}^{2}, 26-30 \%$ of the total above-ground biomass, and it was concluded that above-ground standing crop of stand-I was $256-266 \mathrm{~g} / \mathrm{m}^{2}$. This value also agrees well with the August-value, $265 \mathrm{~g} / \mathrm{m}^{2}$, which was obtained from the monthly sampling of three $1 \mathrm{~m}^{2}$ quadrats (Fig. 2-A).

Some data on the above-ground standing crop in dry weight of Miscanthus 
sinensis-type community and other herbaceous communities in various grasslands in Japan are compared in Table 3. The above-ground standing crop of $376 \mathrm{~g} / \mathrm{m}^{2}$ which was estimated in stand-II of Kirigamine grassland is relatively small in comparison with those of other $M$. sinensis grasslands in Japan, in most of which the values are generally in the range from 400 to $600 \mathrm{~g} / \mathrm{m}^{2}$, and a value of $2180 \mathrm{~g} / \mathrm{m}^{2}$ reported by Yamane et al. is exceptionally large*. Annual mean air temperature and annual mean rainfall in these montane grasslands in Japan range from ca. $5^{\circ}$ to ca. $14^{\circ}$, and from ca. $1600 \mathrm{~mm}$ to ca. $2500 \mathrm{~mm}$, respectively.

Data in Table 3 also show the above-ground standing crop of other types of herbaceous communities, among which some tall herb communities, such as Polygonum sachalinense, Aconitum japonicum, Cacalia hastata and Cirsium nipponicum, have

Table 3. Above-ground standing crop (oven-dry weight $\mathrm{g} / \mathrm{m}^{2}$ ) of various grasslands in Japan.

\begin{tabular}{|c|c|c|c|c|c|}
\hline No. ${ }^{\dagger}$ & Dominant species & $\begin{array}{l}\text { Standing } \\
\text { crop }\end{array}$ & $\begin{array}{l}\text { Sampling } \\
\text { area }\end{array}$ & $\begin{array}{l}\text { Sampling } \\
\text { date }\end{array}$ & Locality \\
\hline 1 & $\begin{array}{l}\text { Montane grassland } \\
\text { Miscanthus sinensis }\end{array}$ & 376 & $25 \mathrm{~m}^{2} \times 12$ & Aug. 27, '59 & Kirigamine \\
\hline 2 & Arundinella hirta & 260 & $25 \mathrm{~m}^{2} \times 20$ & Aug. 25, '59 & Kirigamine \\
\hline 3 & Miscanthus sinensis & $433-840$ & $4 \mathrm{~m}^{2} \times 5$ & Nov. $4-7, ' 61$ & Hijûdai \\
\hline 4 & Miscanthus sinensis & $590-1024$ & $4 \mathrm{~m}^{2}$ & Sep. $10-21, ' 55$ & Aso \\
\hline 5 & Miscanthus sinensis & $(452)$ & $1 \mathrm{~m}^{2} \times 1024$ & Early Sep., '55 & Kawatabi \\
\hline 6 & Miscanthus sinensis & $790-2180$ & $4 \mathrm{~m}^{2}$ & Aug., '55 & Kawatabi \\
\hline 7 & Miscanthus sinensis & 570 & $0.25 \mathrm{~m}^{2} \times 6$ & mid-Aug., '60 & Ôsumi \\
\hline 8 & Sasa nipponica & 242 & $1 \mathrm{~m}^{2}$ & Aug. 25, '60 & Kirigamine \\
\hline 9 & Sasa nipponica & 1701 & $0.25 \mathrm{~m}^{2}$ & Jul. 14, '57 & Kirigamine \\
\hline 10 & Sasa nipponica & 380 & $4 \mathrm{~m}^{2}$ & Aug., '55 & Kawatabi \\
\hline 11 & Sasa ozeana & $1408-1690$ & $0.25 \mathrm{~m}^{2}$ & Aug. $6-8, ' 51$ & Ozegahara \\
\hline 12 & $\begin{array}{l}\text { Lowland grassland } \\
\text { Solidago altissima }\end{array}$ & 1370 & $1 \mathrm{~m}^{2}$ & Sep. 13, '63 & Toride \\
\hline 13 & $\begin{array}{l}\text { Tall herbage } \\
\text { Polygonum sachalinense }\end{array}$ & 1190 & $1 \mathrm{~m}^{2}$ & Aug. 14, '63 & Hakkôda \\
\hline 14 & Polygonum sachalinense & 346 & $4 \mathrm{~m}^{2}$ & Aug. 11, '57 & Hakkôda \\
\hline 15 & $\begin{array}{l}\text { Angelica ursina \& } \\
\text { A. edulis }\end{array}$ & 543 & $4 \mathrm{~m}^{2}$ & Sep. $11, ' 57$ & Hakkôda \\
\hline 16 & Aconitum japonicum & 1000 & $4 \mathrm{~m}^{2}$ & Sep. $10,{ }^{\prime} 57$ & Hakkôda \\
\hline 17 & Artemisia gigantea & 978 & $0.25 \mathrm{~m}^{2}$ & Aug. 9, '52 & Ozegahara \\
\hline 18 & Cacalia hastata & $422-1041$ & $0.25 \mathrm{~m}^{2}$ & Aug. 4-9, '51 & Ozegahara \\
\hline 19 & Phragmites communis & 610 & $0.25 \mathrm{~m}^{2}$ & Aug. 2, '50 & Ozegahara \\
\hline 20 & Cirsium nipponicum & 1613 & $0.25 \mathrm{~m}^{2}$ & Aug. 9, '52 & Ozegahara \\
\hline 21 & $\begin{array}{l}\text { High moor } \\
\text { Moliniopsis japonica }\end{array}$ & $270-324$ & $0.25 \mathrm{~m}^{2}$ & Aug. $6-9,{ }^{\prime} 51$ & Ozegahara \\
\hline 22 & Carex middendorffi & $183-532$ & $0.25 \mathrm{~m}^{2}$ & Jul. $7-8, ' 51$ & Ozegahara \\
\hline
\end{tabular}

$\dagger(4)$, Aomine $^{9)}$; (5), Shimada ${ }^{16,17)}$, estimated from fresh weight $\left(1272 \mathrm{~g} / \mathrm{m}^{2}\right)$ assuming that dry weight percentage of Miscanthus sinensis was $35.5 \%$; $(6,10)$, Yamane et al. ${ }^{19)}$; Kusumoto ${ }^{11)}$; (12), Iwaki \& Takada, unpublished data; (9), Oshima ${ }^{23)}$; $(11,17-22)$, Hogetsu et al. ${ }^{24)}$; (13), Iwaki \& Monsi, unpublished data; (14-16), Midorikawa.22)

* Very high value of above-ground standing crop, $1530 \mathrm{~g}$ dry weight $/ \mathrm{m}^{2}$, was observed by Iwaki, H. and Takada, K. at Toride, Ibaraki Prefecture, on October 16, 1964. This value is the mean of four quadrats, each $4 \times 4 \mathrm{~m}^{2}$ in size. 
shown very large above-ground standing crop exceeding $1000 \mathrm{~g} / \mathrm{m}^{2}$. It should be noted here that standing crop data for Sasa communities can not be compared directly with those of other herbs, since the average life span of culms in the former is at least two years ${ }^{23)}$.

\section{Summary}

1. The productive structures of Miscanthus sinensis- and Arundinella hirta-type communities in Kirigamine grassland, Nagano Prefecture, were investigated in August of 1959, using the stratified-clip method. In the former, the upper layer was mostly occupied by $M$. sinensis and the lower layer by other forbs, showing marked vertical stratification (Fig. 1-B). In the latter, no clear stratification was found and greater part of the foliage was distributed in the lowermost layer, $0-20 \mathrm{~cm}$ above ground-level (Fig. 1-A).

2. Above-ground standing crop of the whole vegetation began to increase from early May and reached their maxima by late August (Arundinella type, ca. $270 \mathrm{~g} / \mathrm{m}^{2}$ ) or early September (Miscanthus type, ca. $380 \mathrm{~g} / \mathrm{m}^{2}$ ), then decreased rapidly towards. the end of growing season in November (Fig. 2).

Underground standing crop ranged from 487 to $717 \mathrm{~g} / \mathrm{m}^{2}$ for Miscanthus type, and from 402 to $502 \mathrm{~g} / \mathrm{m}^{2}$ for Arundinella type, showing no clear seasonal trends during the growing period (Table 1). Mean value in winter of $600 \mathrm{~g} / \mathrm{m}^{2}$ was observed in Miscanthus-type community.

Amount of litter was maximal at the end of growing season, in October or November, ca. $430 \mathrm{~g}$ dry weight $/ \mathrm{m}^{2}$ for Miscanthus type and ca. $200 \mathrm{~g} / \mathrm{m}^{2}$ for Arundinella type.

3. Characteristic seasonal change in above-ground standing crop was shown for each constituent species of the communities (Fig. 3).

Miscanthus sinensis assumed the largest proportion (about 40-60\%) in total aboveground standing crop of Miscanthus-type community throughout the growing season, and it had a seasonal peak of ca. $240 \mathrm{~g}$ dry weight $/ \mathrm{m}^{2}$ in early September. Compositae species, such as Aster, Solidago, and Anaphalis, followed M. sinensis in rank of standing crop.

In Arundinella-type community, grasses made the largest contribution to aboveground standing crop especially in late August, when the seasonal maximum, ca. $180 \mathrm{~g}$ dry weight $/ \mathrm{m}^{2}$, of grasses was attained. Liliaceae species, and Scabiosa japonica showed their seasonal maxima in June and in August, respectively.

Seasonal peaks of the top weight/total plant weight ratio (\%) were observed in late June for Liliaceae species, in late July for Compositae species, in August for Scabiosa japonica, and in late August or later for Miscanthus sinensis and other grasses (Fig. 4).

4. Above-ground standing crops of these communities were compared with those of other Japanese herbaceous communities (Table 3).

The authors should like to express their sincere thanks to Prof. M. Monsi of the University of Tokyo, for his valuable advice and suggestion, and also to $\mathrm{Mr}$. $T$. Ushijima of the Tokyo University of Agriculture and Technology, and the colleague of the Ecological Laboratories of the Tokyo Metropolitan University and of the University of Tokyo, for their kind assistance during the work in the field and in the laboratories. 


\section{References}

1) Midorikawa, B., Iwaki, H., and Hogetsu, K., Bot. Mag. Tokyo 77: 260 (1964). 2) Bray, J. R., Lawrence, D. B., and Pearson, L. C., Oikos 10: 38 (1959). 3) Bray, J. R., Can. J. Bot. 41: 65 (1963). 4) Odum, E. P., Ecol. 41: 34 (1960). 5) Pearsall, W. H., and Gorham, E., Oikos 7: 193 (1956). 6) Penfound, W. T., Limnol. \& Oceanogr. 1: 92 (1956). 7) Wiegert, R. G., and Evans, F. C., Ecol. 45: 49 (1964). $\quad$ 8) Westlake, D. F., Biol. Rev. $38: 385$ (1963). 9) Aomine, S., Chemical Composition of Soil and Wild Grasses and Legumes in Aso Grassland (Kumamoto Prefecture, 1956). 10) Ito, I., and Yamane, I., Bull. Inst. Agr. Res. Tohoku U. 7: 33 (1955). 11) Kusumoto, T., Sci. Rep. Kagoshima U. 10: 27 (1958).

12)

Misc. Rep. Res. Inst. Nat. Resour. 54-55: 101 (1961). 13) Kurasawa, H. and Sakamoto, M., ibid. 40: 81 (1956). 14) Numata, M., Sôchi Seitai 4: 4 (1964). 15) Ôseko, M., Studies on the Grasslands in Japan (Kôrin-kai, Tokyo, 1937). 16) Shimada, Y., Sci. Rep. Res. Inst. Tohoku U. 9: 117 (1958). 17) , Sôchi Seitai 4: 13 (1964). 18) Suzuki, T., J. Jap. For. Soc. 40: 299 (1958). 19) Yamane, I., Ito, I., Sato, K., and Kumada, D., Sci. Rep. Res. Inst. Tohoku U. 9: 1 (1958). 20) Yoshida, S., Sugano, S., Iizumi, S. and Yamane, I., Bull. Inst. Agr. Res. Tohoku U. 7: 33 (1955). 21) Monsi, M. and Saeki, T., Jap. J. Bot. 14: 22 (1953). 22) Midorikawa, B., Ecol. Rev. 15: 83 (1959). 23) Oshima, Y., Bot. Mag. Tokyo 74: 199 (1961). 24) Hogetsu, K., Ichimura, and Hori, S., Oshima, Y., Kasanaga, H., Ono, H., and Takada, K., Scientific Researches of the Ozegahara Moor, 313 (Nihon-Gakujutsu-Shinkôkai, Tokyo, 1954).

\section{摘要}

岩城英夫*.侽川文次郎**.宝月欣二**: 霧ヶ峯草原の生産力と栄意元素循環に関する研 究 II. 現存量の季節的变化

長野県霧ケ峯のススキ型およびトダシバ型群落の年間純生産量を明らかにするため, 地上部・地下部現存 量(乾量)㧍よび植物遺体(litter)量の季節的変化をしらべまた各種群落の生産構造を明らかにした。

1。ススキ型，トダシバ型，およびササ型群落の生産構造を層別刚取法により調查した(Fig. 1-A, B , C). ススキ型群落 (草丈 $120 \mathrm{~cm}$ )にはかなり明暸な階層分化がみられ，ススキの葉は主として $40 \mathrm{~cm}$ 以の上層 に，他の草本類は下層にそれぞれ分布するのがみられた。群落下層の相対照度は低く，3〜5\%であった。

トダシバ型群落(草丈 $80 \mathrm{~cm}$ ) の生産棈造には，ススキ型とことなって，明瞭な階層分化はみられず， た最下層 $(0 \sim 20 \mathrm{~cm})$ に大部分の葉が分布しているのがみられた.

2. ススキ型群落の地上部現存量は9月上旬に極大值 (約 $380 \mathrm{~g} / \mathrm{m}^{2}$ ) を示した (Fig. 2-B).一方, トダシ バ型群落の地上部は8月下旬に極大を示し, その現存量は約 $270 \mathrm{~g} / \mathrm{m}^{2}$ であった (Fig. 2-A).

生育期間中の地下部現存量は，ススキ型群落 $487 \sim 717 \mathrm{~g} / \mathrm{m}^{2}$, トダシバ型群落 $402 \sim 502 \mathrm{~g} / \mathrm{m}^{2} て ゙ ，$ 明瞭な 季節的変化の傾向はみられなかった (Table 1). 冬季に打けるススキ型群落の地下部平均現存量は $600 \mathrm{~g} / \mathrm{m}^{2}$ であった。また, 植物遺体量は, 夏季に少なく, 10 月〜 11月に最大(ススキ型: $434 \mathrm{~g} / \mathrm{m}^{2}$, トダシバ型: $208 \mathrm{~g} /$ $\mathrm{m}^{2}$ )となるよらな季節的变化を示した(Table 1).

3. 群落を構成する备植物の地上部現存量は，それぞれ特有の季節的変化を示した $(F i g .3-\mathrm{A}, \mathrm{B})$.

ススキ型群落では，ススキの地上部現存量は生育期間を通じて全体の40〜60\%を占め，9月上旬には極大 值 $240 \mathrm{~g} / \mathrm{m}^{2}$ を示した。キク科草本の現存量はススキに次いで大きく，その極大は8月下旬〜9月上旬にみら れた。

トダシバ型群落では，トダシバなどイネ科植物は 8 月下旬に地上部現存量の極大 $\left(\right.$ 約 $\left.180 \mathrm{~g} / \mathrm{m}^{2}\right)$ を示した。 一力，ユリ科草本(主としてニッコウキスゲ)は6月に，マッムシソウは 8 月に，それぞれ地上部現存量の極大 を示した。

また各植物の地上部/(地上部十地下部)の乾量比も，それぞれ特有の季節的変化を示した。すなわち，ユ リ科草本は6月下旬，キク科草本は7月下旬，マッムシソウは8月，そしてススキなどイネ科植物は8月下旬 以降に，それぞれこの比の極大を示した (Fig. 4).

4. 霧ケ峯のススキ型およびトダシバ型群落の8月下旬に拈ける地上部現存量を大面積の坪刚によって测 定し，これを日本各地域の山地草原，大形多巡草原，湿原などの地上部現存量と比較した (Table 3). (*查京大学理学部植物学教室, **東京都立大学理学部生物学教室) 